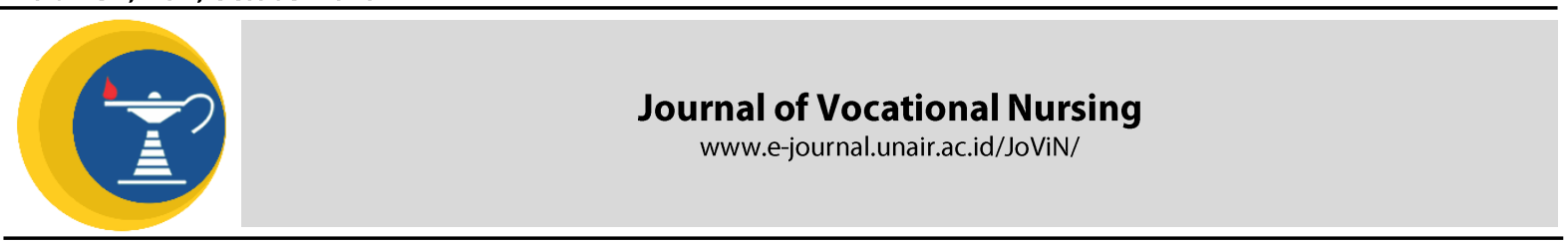

\title{
COPING MECHANISMS IN ADOLESCENTS WHO HAVE VULGENT ACNE IN MTS ASSA'ADA CLASS 3 KANDANGAN SAMBENG DISTRICT
}

Research Report

Ali Sairozi

DIII Nursing Study Program, Departement of Health, Faculty of Vocational Studies, Universitas Airlangga

\section{ABSTRACT}

Introduction: Physical conditions in adolescence are a source of changes in selfidentity and self-concept, many of which are caused by physical images. As in adolescents who have acne or acne, where this often occurs in adolescents aged 15-19 years in women and 17-21 in men. One of the effects of the occurrence of acne in adolescents is the emergence of coping mechanisms that are adaptive mall. This is reinforced from the results of the initial survey conducted by researchers in grade 3 students at MTs Assa'ada Kandangan, Sambeng District, 10 students obtained data that 7 or $70 \%$ of students with acne used a maladaptive coping mechanism and 3 or $30 \%$ of students used a mechanism adaptive coping. The purpose of this study was to identify the picture of coping mechanisms in adolescents who have acne vulgaris at MTs Assa'ada class 3 Kandangan Sambeng District.

Methods: The design used in this study was descriptive with sampling techniques using total sampling and the instruments used were questionnaires with closed questions to respondents. From the results of the questionnaire data grouping and data tabulation were carried out by descriptive method and transformed in the form of narratives and percentages.

Results: The results of the study showed that most respondents had adaptive coping mechanisms. This may be influenced by several factors including: gender and age. Conclusion: The experience factor of the respondents is quite adequate this is because of the time the acne appears itself. If the acne arises the respondent has an effective method or trick in the association to show his confidence. The occurrence of acne that is common in adolescence, then over time teenagers will be able to adjust to the situation, because it is considered normal thing and often occurs in adolescence.
ARTICLE INFO

Recived 18 October 2020

Accepted 26 October 2020

Online 29 October 2020

*Correspondence:

Ali Sairozi

*Email:

ali.sairozi@vokasi.unair.ac.id

Keywords:

Adolescence, Koping Mechanism, Acne Vulgaris

\section{INTRODUCTION}

Adolescence is a period in which individuals in society are said to be indeterminate and confusing. Such status causes difficulties for adolescents because at this time, adolescents experience a period of transition from children to adults both physically and psychologically. Even physical changes that occur are the primary symptoms of adolescent growth while psychological changes arise due to physical changes (Sarlito Wirawan, 2012). Enagers are very sensitive to their appearance, the slightest change in themselves, especially in terms of the physical one that leads to one negative thing, is not escaped from observation, because at this time, teens began to realize how important the meaning of good relationships with peers and the surrounding community. Physical condition in adolescence is a source of change in self-identity and self-concept, much dissatisfaction with oneself is caused by physical images. As in adolescents who have acne or acne, they are mostly embarrassed or feel inferior, especially if they cause a rash, especially in the face, neck and back (Clara R Pudjijogyanti, 1998: 20).

Acne or acne is a skin disease that occurs due to chronic inflammation of pilosebasea follicles which are characterized by blackheads, papules, pustules, cysts in the place of predilection (Wasitaatmojo BC, 2010). Teenagers and acne are things that cannot be separated. Almost all people have experienced acne disorders, where this often occurs in adolescents aged 15-19 years in women and 17-21 in men. 
This is reinforced from the results of the initial survey conducted by researchers in grade 3 students at MTs Assa'ada Kandangan, Sambeng District, 10 students obtained data that 7 or $70 \%$ of students with acne used a maladaptive coping mechanism and 3 or $30 \%$ of students used a mechanism adaptive coping despite having experienced problems with acne. Based on the data above, the problem of this study is that there are still many students who have acne using adaptive coping mechanisms.

Acne is a skin disorder that is a source of anxiety for boys and girls. The fertility of acne makes them more concerned with his appearance. Concern was greater for male adolescents, because they were aware that acne reduced physical attractiveness and because they could not use cosmetics to cover it like girls. This can be seen from the percentage of male and female adolescents aged 12-17 who feel disturbed by the condition of zits with high levels following medical standards (Elizabeth B. Hurlock, 2011).

Disorders that can arise in adolescents who have zits are causing these adolescents to become less confident in relationships that will ultimately affect mental and emotional development and indirectly will also affect their intellectuals, namely learning achievement will decrease. Besides that, one of the effects of the occurrence of acne in adolescents is the emergence of coping mechanisms that are mal adaptive which is an emotional reaction that always occurs in every human being. Where koping is used, it is not the same for everyone, this can be influenced by several factors including: education, socio-cultural knowledge and experience.

The coping mechanism is a reaction that continuously moves a mechanism to maintain a state of equilibrium to a certain extent in order to maintain its life. Where in this case the coping mechanism is in two forms, namely the taskoriented adjustment method or task oriented and the ego defense mechanism or ego defense oriented (WF. Maramis, 2010).

The efforts that can be done by nurses in overcoming this is to provide counseling on things that can cause acne and ways to overcome them and also convince them that the emergence of acne in adolescence naturally occurs along with hormonal changes, as long as the acne is in normal limit.

\section{MATERIALS AND METHODS}

The design used in this study is descriptive. In this study the researchers wanted to know the description of coping mechanisms in adolescents who have acne vulgaris at MTs Assa'ada class 3 Kandangan Sambeng District. In this study, the population is all students in class 3 Kandangan MTs Assa'adah Sambeng Subdistrict who have acne vulgaris as many as 40 students who meet the inclusion criteria: 1) all grade 3 students at MTs Assa'ada Kandangan Sambeng District have Acne Vulgaris, 2) willing to be studied and sign informed consent.

The sampling technique in this study uses total sampling, which is a sample selection technique using the entire population as the study sample. In this study the research variable is a coping mechanism for students who have acne vulgaris. After getting permission to do the research, the researcher asked the respondents for approval as research subjects, namely students at MTs Assa'ada class 3 Kandangan Sambeng District. After obtaining permission from the related parties, among others, from the Academic and Principals of MTs Assa'ada Kandangan, Sambeng Subdistrict, the researcher approached the research respondents to get approval to become respondents as the subject of the research. In this study the instruments used were questionnaires with closed questions to respondents about various descriptions relating to coping mechanisms in students who experienced acne vulgaris in the form of descriptions of adaptive coping mechanisms and adaptive mall coping mechanisms. Then after adding up a scoring and coding technique is carried out by: 1 ) adaptive mall coping, if <mean, code 1,2) adaptive coping, if $>$ mean, code 2. From the results of the questionnaire the data is grouped and tabulated by descriptive and transformed data in the form of narration and percentage 


\section{RESULTS}

Table 1 The frequency distribution of respondents by gender at MTs Assa'ada Class 3 Kandangan Sambeng District, Lamongan Regency

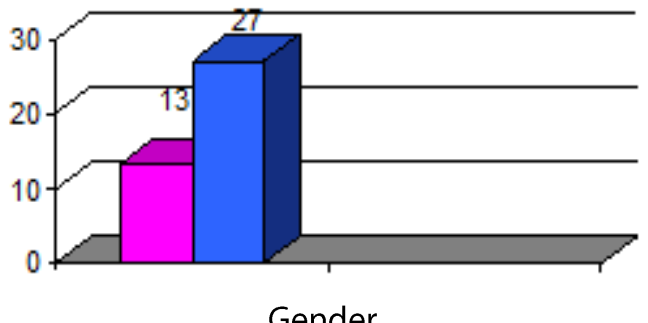

$\square$ Male

드ale

Gender

Shows that the majority of respondents (67.5\%) were female and almost half (32.5\%) were male

Table 2 The frequency distribution of respondents by age at MTs Assa'ada Class 3 Kandangan Sambeng District, Lamongan Regency

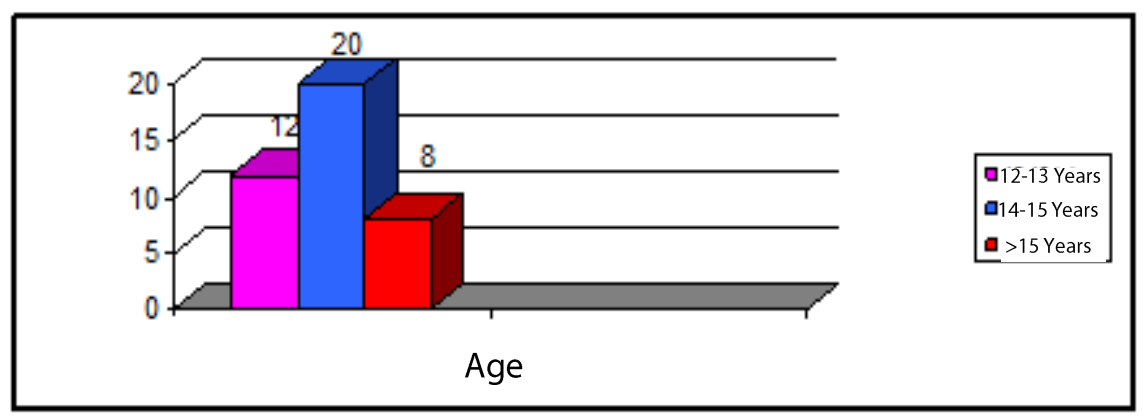

Shows that the majority of respondents $14-15$ years old and a small proportion (20\%) aged more than 15 years.

Table 3 The frequency distribution of respondents by coping mechanism at MTs Assa'ada Class 3 Kandangan Sambeng District, Lamongan Regency

\begin{tabular}{|c|c|c|c|}
\hline No & Coping Mechanism & Total & Percentage \\
\hline 1 & Maladaptive & 14 & 35,0 \\
\hline 2 & Adaptive & 26 & 65,0 \\
\hline \multicolumn{2}{|c|}{ Total } & 40 & 100 \\
\hline
\end{tabular}

Shows that the majority of respondents (65\%) of respondents have an adaptive coping mechanism and almost half (35\%) have a maladaptive coping mechanism.

\section{DISCUSSION}

The results showed that most respondents had adaptive coping mechanisms. This may be influenced by several factors including: gender and age.

The results of the study in Figure 4.1 show that the majority of respondents were female. Most teens want a beautiful and attractive face when viewed. Acne is a skin disorder that is a source of anxiety for boys and girls. The fertility of acne makes them more concerned with his appearance. This concern was felt more by male adolescents, because acne can reduce physical attractiveness and because they cannot use cosmetics to cover it like girls, so it is in accordance with the results of research that most women are more adaptive in dealing with this situation.

The above is in accordance with the opinion of Sarlito Wirawan (2012) which states that women are more social in nature so that they are more easily influenced and easier to learn more simple roles and tasks because women tend to listen more. While men are more influenced by their environment, because they tend to see more, 
so they are eager to achieve by showing their strength.

The experience factor of the respondents is quite adequate this is because of the time of the appearance of the acne itself. If acne arises when the respondent is in class 1 or class 2, then the respondent has an effective method or trick in the association to show his confidence. This is corroborated by the opinion of Notoatmodjo (2007) who states that experience is a good teacher and is a source of knowledge, so experience will affect the knowledge, attitudes and skills of a person in making adjustments.

Acne or acne is a skin disease that occurs due to chronic inflammation of pilosebasea follicles which are characterized by blackheads, papules, pustules, cysts in the place of predilection (Wasitoatmojo, 2010). This reinforces the assumption that adolescents and zits are inseparable. Almost everyone has experienced a breakdown of acne, which often occurs in adolescents aged 15-19 years in women and 17-21 in men, which is a source of anxiety for boys and girls, because it can reduce physical attraction and affect mental and emotional development.

Besides that acne will cause a feeling of lack of confidence in adolescents, because it will reduce its physical attractiveness, the slightest appearance in the physical does not escape from observation, although it has tried to use cosmetics to hide physical forms that are not liked but not enough to show attractive forms. So that it will cause feelings of shame and changes in social relations, which can influence coping mechanisms used to respond to this. But with the occurrence of acne that is common in adolescence, then over time teens will be able to adjust to the situation, because it is considered normal and often occurs in adolescence.

The results of this study are in accordance with the theory of Stuard and Sundeen (2008) which states that coping mechanisms are ego defense mechanisms to protect themselves in the face of painful self-perceptions, where the mechanism is in the adaptive range to adaptive malls. On the other hand, it was also strengthened by the opinion of WF. Maramis (2010) who argues that the coping mechanism is a reaction that moves continuously a mechanism to maintain a state of balance within a certain extent in order to maintain life, in this case is in the face of the emergence of acne vulgaris.

\section{CONCLUSION}

From the results of research and discussion on the description of coping mechanisms in adolescents who have acne vulgaris, the researcher can draw a conclusion: "most respondents have adaptive coping mechanisms".

\section{REFERENCES}

Anderson, Elizabet T, (2007). Buku Ajar Keperawatan Komunitas Teori dan Praktik, EGC : Jakarta.

Arikunto, Suharsimi. (2014). Prosedur Penelitian Suatu Pendekatan Praktik. Jakarta : Rineka Cipta.

Adhi Djuanda, dkk. 2011. Ilmu Penyakit Kulit dan Kelamin Edisi 6. Jakarta: Fakultas Kedokteran Universitas Indonesia.

Carpenito, L.J. (2012). Diagnosis keperawatan :Buku saku / Lynda juall Carpenitomoyet; alih bahasa, Fruriolina Ariani, Estu Tiar; editor edisi bahasa Indonesia, Ekaanisa Mardela Edisi 13. Jakarta: EGC.

Clara, R. Pudjijogyanti. 1998.Konsep Diri Dalam Pendidikan. Jakarta: Arcan

Hawari, Dadang. 2011. Manajemen Stres Cemas dan Depresi. Jakarta: Balai Penerbit FKUI.

Elizabeth B. Hurlock. 2011. Psikologi Perkembangan. Jakarta: Erlangga.

Maramis, W.F. 2010.Catatan Ilmu Kedokteran Jiwa Edisi 2. Surabaya :Airlangga University Press.

MarwaliHarahap, 2000. Ilmu Penyakit Kulit : Acne Vulgaris. Jakarta :Hipokrates. $\mathrm{H}$.

Notoatmodjo, S. 2007. Kesehatan Masyarakat IImu dan Seni. Jakarta :RinekaCipta.

Nursalam. 2011. Konsep Dan Penerapan Metodologi Penelitian Ilmu Keperawatan. Jakarta: Salemba Medika.

Sarlito Wirawan Sarwono. 2012. Psikologi Remaja. Jakarta: PT. Raja Grafindo Persada.

Sofyan, S Willis. 2010. Remaja dan Masalahnya. Bandung: CV Alfabeta.

Sri Rumini dan Siti Sundari.2004. Perkembangan Anak dan Remaja. Jakarta: PT. Asdi Mahasatya.

Stuart, G. W. \& Sundeen. 2008 . Buku Saku Keperawatan Jiwa Edisi 3 Alih Bahasa, Achir Yani, Editor Yasmin Asih. Jakarta: EGC.

Wasitaatmadja SM. 2010. Ilmu Penyakit Kulit dan Kelamin Edisi ke-6. Jakarta : Fakultas Kedokteran Universitas Indonesia. 